\title{
SOCIAL CONSTRUCTIONISM AND THE EFFECTS OF MEDIA'S PORTRAYAL OF NIGERIA'S ECONOMIC RECESSION ON FOREIGN DIRECT INVESTMENT
}

\author{
DRUŠTVENI KONSTRUKCIONIZAM I UČINCI MEDIJSKOG \\ PRIKAZA NIGERIJSKE GOSPODARSKE RECESIJE NA STRANE \\ IZRAVNE INVESTICIJE
}

\author{
Beryl Annette Ehondor, Aifuwa Edosomwan \\ Pan-Atlantic University, Lagos, Nigeria \\ Pan-Atlantsko Sveučilište, Lagos, Nigerija
}

\section{Abstract}

Although Nigeria has the largest economy in Africa, it has been bedeviled by various issues in recent times, which has led to its experience of an economic recession. Its over-dependence on foreign products, the activities of militants and pipeline vandals in the Niger-Delta, poor economic planning and the delayed budget signing are some of the issues that have being credited to the fall into recession. However, some economists have suggested that Nigeria's economy has the potential to rise from the recession and have identified the inflow of foreign direct investments as one of the key factors that will contribute to the rise. On the other hand, the media's reporting of Nigeria's recession seems to have caused mixed reactions from among the public who worry about their daily bread. Potential investors, both local and foreign, are also not left out in the expression of uncertainty. Since they rely on the media to provide information on the situation of the Nigerian economy, the power of the media in the making or marring of the government's encouragement of FDI to boost the economy cannot be underestimated. The power of the media, which appears to be able to determine or construct the position and perception of individuals/organisation follow it can be related to the theory of social constructionism. Social ISSN 1330-0067
Sažetak

Iako Nigerija ima najveće gospodarstvo u Africi, u posljednje vrijeme bila je opterećena raznim problemima, što je dovelo do ekonomske recesije. Prevelika ovisnost o stranim proizvodima, aktivnosti militanata i naftovodnih vandala $u$ delti Nigera, loše ekonomsko planiranje i odgođeno potpisivanje proračuna neka su od pitanja koja se pripisuju padu u recesiju. Međutim, neki su ekonomisti sugerirali da nigerijsko gospodarstvo ima potencijal porasta nakon recesije i identificirali su priljev stranih izravnih ulaganja kao jedan od ključnih faktora koji će pridonijeti rastu. $S$ druge strane, čini se da su medijski izvještaji o recesiji u Nigeriji izazvali pomiješane reakcije javnosti koja brine o svom svakodnevnom kruhu. Potencijalni investitori, domaći i strani, također nisu izostavljeni u izražavanju nesigurnosti. Budući da se oslanjaju na medije da će pružiti informacije o stanju nigerijskog gospodarstva, moć medija u stvaranju ili ometanju vladinog poticanja izravnih stranih ulaganja ne može se podcijeniti. Moć medija, za koje se čini da mogu odrediti ili konstruirati položaj i percepciju pojedinaca/organizacije nakon toga, može se povezati s teorijom društvenog konstrukcionizma. Društveni konstrukcionizam sugerira da mediji imaju sposobnost selektivne reprodukcije i konstruiranja stvarnosti svake situacije - $\mathrm{u}$ ovom 
constructionism suggests that the media's have the capacity to selectively reproduce and construct the reality of any situation - in this case, Nigeria's recession. However, it also acknowledges that the meanings offered by the media can be negotiated or rejected by those to whom it is directed. This study explores the capacity of the media's construction of Nigeria's economic recession to influence the inflow of foreign direct investments.

\section{Introduction}

Economic recession appears to have led to the decline in the inflow of foreign direct investments into Nigeria. Correspondingly, media stories show that the report published by the National Bureau of Statistics on foreign direct investment (FDI) state that although Nigeria recorded foreign portfolio inflows (in equities, stocks, and bonds), it did not enjoy direct capital investment inflows in the third quarter of 2016 /1/. The country's economy that appeared to have grown to be one of the top foreign investments' spot in Africa did not suddenly suffer an economic set back. Moreover, various analysts and media reports have listed a number of factors besides foreign direct investments.

Other factors that seem to have led to Nigeria's economic recession and contributed to foreign investments degeneration include poor economic planning, high inflation rate, high interest rate, high taxation and policy instability /2/, /3/. First, there have been delays in the passing of the national budget and an altogether weak implementation of economic planning. Second, although Nigeria's inflation appears to have dropped during the first and second quarters of 2017 , it still stands at over 17 percent /4/. This high inflation rates are reflected in the increased prices of goods and services between 2016 and 2017. Additionally, high interest and tax rates generally do not attract investors and even threaten or kill small businesses and startups. All of these and other factors have contributed to the precarious state of Nigeria's economic stability.

On the other hand, more worrying is the portrayal of the country's economic recession in ISSN 1330-0067 slučaju, recesije u Nigeriji. Međutim, također se priznaje da se o značenjima koja nude mediji mogu pregovarati ili odbaciti oni kojima su upućena. Ova studija istražuje sposobnost medijske konstrukcije gospodarske recesije Nigerije da utječe na priljev izravnih stranih ulaganja.

the media space. The media is generally viewed as the link between the government and the people i.e. the people rely on the media to be updated on the activities of the government while the government also depend on the media as a feedback channel on its activities and plans. Conversely, the Nigerian public rely on the media for information on the activities of its government and reports on the economic situation. However, the depiction of the country's recession appears to have been exaggerated by a number of media outlets the Nigerian public depends on. While some press editorials and report appear to simply give an expository narration on the state of the nation, some others, through the use of "strong language" practically raise an alarm on the financial state of the nation. The compositions of such reports that create panic seem to further strengthen their position by further enumerating the problems and failures of the past and present governments, with no ray of hope. On the whole, the public within and outside the country are paying close attention to media reports in order to gain insight in to the state of Nigeria; potential investors are also paying attention and would likely make their decisions to invest or not invest depending on their perception and forecast of the nation's economic situation.

Media reports may pose a danger when they focus only or mainly on negatives and the failures of the government. Likewise, media reports that draw attention to the positives and moves of the government toward restoring a delicate situation, like the issue in question, will likely raise hopes and encourage local and foreign investors. Nigeria is not the first country to suffer

Coden: IORME7 
a recession and will definitely not be the last. Countries, including the United States of America considered a great world power, have suffered economic recession at one point or another and recovered from it. The restoration of a country's economy from a recession requires strategic decisions and actions, which require all hands to be "on deck". The decisions and actions particularly rest in the hands of those elected to lead the nation and in the case of $\mathrm{Ni}$ geria, all arms of the government are implicated, including the executive, the legislative and the judiciary. Similarly, the media as the fourth branch of the government also have a great responsibility toward contributing to resolve the issue - recession - in its own special way while carrying out its duties $/ 5 /$.

Furthermore, those saddled with the responsibility of managing economic and other affairs of the country require correct and timely report to allocate resources well. The media also have the capacity to provide information that will contribute immensely to the development of more effective economic policies and charge those elected into public office to serve their country increase good governance, conditions of which are necessary for improving the economy of any nation. All in all, the media have the power to foster social (as well as economic) change by the ideas they disseminate $/ \mathbf{6} /$.

The economic slump Nigeria is experiencing have affected businesses, including small and medium scaled businesses and has forced some to close down. Foreign currency exchange rates (for instance, dollar and pounds) have risen twice more than its value before the Buhari administration. The flow of foreign direct investments into the country appears to have also dropped, and this has further affected the already bad situation of the country. Some experts propose that one of the many solutions to reviving the economy is the renewed inflow of foreign direct investments. However, since potential investors would be watching out for profitable opportunities with little or no risks, it is important for the Nigerian government to improve the situation and encourage the inflow of investment in all possible ways. Moreover, the media seems well positioned to present the efforts of the government at making the economy suitable for foreign and local investments. Although first-hand knowledge of the current situation of Nigeria's economy is made available through financial and economic experts and organisations, the real dissemination of such information by mass communication is handled by the media.

Furthermore, many rely on the media to inform the Nigerian public as well as investors that the situation will change for better, and they rely on the media to provide useful updates and direction on the issue. The power of the media in the making or marring of the government's encouragement of FDI to boost the economy cannot be underestimated because potential investors will likely public depend on the media to inform and educate them on social issues such as this and its consequences on the economy. This study believes that the Nigerian media has the capacity to construct a reality that will favour or negatively affect the choice of investors. While social constructionism posits that the media have the capacity to construct reality, it also acknowledges that the meanings offered by the media can be negotiated or rejected by those to whom it is directed. This study therefore investigates the media's capacity to influence foreign direct investments following the various media constructions of $\mathrm{Ni}$ geria's economic recession.

The study examined if there is a correlation between the reports on FDI by the media and the inflow of foreign investments in Nigeria. Attention is drawn to the significance of media reports to the inflow of FDI into Nigeria. Findings are useful to media practitioners, as they are expected to provide balanced representations and consider national interests in their respective reports. Finally, the paper provides information on the media's role and concern in the restoration of Nigeria's economic situation. 


\section{Conceptual Framework}

\section{Nigeria's Economy}

It is no longer news that Nigeria is the most populous country in Africa with an estimated population of over 180 million people /7/. The country's potential as an investment destination has also been growing due to the size of its consumer market and emergent capital markets. Nigeria, with a middle-income mixed economy, has one of the biggest economies in Africa and is one of the biggest oil producers in the world /8/. However, although Nigeria is blessed with so much human and natural resources, it has experienced slow-moving economic growth since the last quarter of 2015 /9/.

The country's economy has been badly hit hard by challenges and unfavourable factors from outside its boundaries such as the crash in the global prices of crude oil. It was recorded that growth decelerated sharply from 6.2\% in 2014 to an estimated $3.0 \%$ in 2015 while inflation rose from $7.8 \%$ to an estimated $9.0 \% / 9 /$. The slow-moving progression is largely credited to a decline in economic activity, which has been significantly worsened by the scanty supply of foreign exchange and further intensified by the foreign exchange limits targeted at a list of forty one importations, some of which are inputs for manufacturing and agriculture related businesses. Moreover, this has led to in reductions in production and down-sizing of employed workers in some sectors. However, with respect to the growing policy concern over the deteriorating economic growth of Nigeria, the Central Bank has moved to cut the cost of borrowing for the public and the private sectors to stimulate the economy $/ \mathbf{9} /$.

Furthermore, the recent economic turmoil experienced by Nigeria has led the government to exploring alternative ways of restoring the country including renewed concentration on diversifying the economy, promoting development in the private sector, and driving employment growth. However, there are various challenges militating against the government's strategic plan to raise the country from the recession. For instance, the potentials of the private sector as the main driver of the economy has not being fully tapped in to because of the challenge of an epileptic power supply, a poor regulatory environment, an anaemic economic and basic infrastructure as well as an almost non-existent access to credit facilities. There is also a growing youth population with little employment opportunities to contend with; job creation is not particularly encouraged. Nigeria's situation is further threatened by the increasing divide between the north and the south. Besides, the Boko Haram insurgency, the herdsmen attacks, the Niger Delta militancy and the Biafra agitation are serious issues that seem to be contributing to the widening gap. Nigeria continues to face human development and security challenges which engenders the increasing number of unemployed and frustrated youths, degrading levels of natural resources, increasing levels of poverty and many more issues /10/. A critical look at all of these issues that have befallen Nigeria gives more light to the many challenges the nation is facing especially the economic recession, which forms part of the subject of this paper.

\section{Economic Recession}

Although there is no officially accepted definition for the term, "Recession," there is a general consensus that the word refers to a period in which economic activity decline $/ \mathbf{1 1} /$. The Central Bank of Nigeria also refers to it as general downturn in economic activity for two consecutive quarters and further point out that such slowdown is usually evident in the drop of GDP, employment rate, investment spending, capacity utilization, domestic income and professional income /12/.

Furthermore, an economic recession is usually generally signaled by a number of factors such as high interest rates, which limits the amount of money available to invest; stock market crash, which drains capital out of businesses; increased inflation, which refers to a general rise in the price of goods and services over a period of time; dropping income, which cannot keep up with the growing inflation; defaulting

Coden: IORME7 
borrowers, who begin to have difficulties with settling their debts and increased essential goods cost, which makes it difficult for people to access food and other basic utilities /13/.

Nigeria entered a recession when the country recorded a declining growth for two successive quarters in early 2016 /14/. Nigeria's recession has been blamed on its overdependence on crude oil export following the global crash in oil prices and increased destruction of oil facilities in the Niger-Delta region by militant groups. Other reasons are its failure to diversify the economy, improve the manufacturing and mining sectors, increase agricultural output and encourage foreign direct investment (FDI) /2/.

\section{Foreign Direct Investments}

Foreign direct investment is a key part of foreign investment. It is largely an investment made to obtain enduring interest in an organisation operating in an economy other than that of the investor, the investor's purpose being an effective voice in the managing or controlling of an organization /15/. FDI is mostly carried out by multinational businesses and it differs from portfolio investment. While FDIs carry control over the borrowing body, portfolio investments may not involve any direct control over the use of lending funds. In recent years, FDI has become even more significant as a vehicle for transmitting resources and technology across state borders $/ \mathbf{1 6} /$.

According to Duce and España /17/, citing the IMF and OECD definitions, direct investment reflects the aim of obtaining a lasting interest by a resident entity of one economy (direct investor) in an enterprise that is resident in another economy (the direct investment enterprise). It is a major tool in the integration of international communities. In addition to its capacity to facilitate globalization, it also contributes to economic stability, stimulates economic expansion and enhances the welfare of societies /18/. FDIs seem to be a major factor in ensuring the economic wellbeing of many developing countries.

One factor that can lead to economic recession but seems to be played down is the drop in the ISSN 1330-0067 confidence of consumers and investors. Consumers are not likely to spend if they perceive that the economy is bad or experiencing a downturn. Similarly, investors will likely avoid markets that are not expected to profit them. Consumer and investor confidence is psychological but have the capacity to impact on any economy.

However, foreign direct investment is generally beneficial to an economy because: it provides capital inflow that will likely create higher output and jobs; it creates long term capital inflows that are sustainable; the benefitting organization's country can profit from improved understanding and expertise of the foreign organisation; it may lead to an increase in remuneration of workers in the benefitting organisation and improve their working conditions because investors are conscious of their organization's public image, especially of working conditions in third world countries $/ 19 /$.

\section{Social Constructionism}

Social constructionism appears to have originated sometime around the 1980s in an effort to come to an understanding of the nature of reality $/ 20 /$. Over the years, various studies in the social sciences and humanities have presented and expatiated different views of the social constructionism theory - from the realist and relativist approaches to the interpretivist and constructivist approaches and so on. The theory engenders a strong debate as to the difference between "reality" and "knowledge". No one study seems to be able to lay claim to presenting an explanation of the term that is generally acceptable to all.

Berger and Luckmann /21/ in their book, "The social contruction of reality", explain that the reality of daily life is socially constructed by human interactions. They make a distinction between the objective reality and subjective reality. For instance, they described some natural phenomena such as the presence of celestial and water bodies as objective. In contrast, they describe an individual's status in

Coden: IORME7 
the society, which can change at any moment, as subjective reality. In summary, they explain that subjective reality is an interpretation of objective reality, therefore making it a socially constructed reality.

However, according to Burr $/ \mathbf{2 2} /$, there are a number of assumptions that seem to be commonly held by social scientists with regard to defining what may qualify as social constructionism. She explains that social constructionism insists that we take a more serious look at the taken-for-granted approach of understanding the world and the human person, and it challenges empiricists and positivists and the view that common knowledge is based on the objective and impartial observation of the world. Also, the view held by each person is usually influenced by the culture and history of their society. Furthermore, our knowledge of the reality around us is formed by daily interactions and actions.

Conversely, with respect to the discussion of this paper, the assumptions of social constructionism in connection with the media could be summarized as follows:

- Society is a construct rather than a fixed reality

- Media provide the materials for reality construction

- Meanings are offered by the media, but can be negotiated or rejected

- Media selectively reproduce certain meanings

- Media cannot give an objective account of social reality

\section{Method}

A total of two hundred foreign direct investment related media reports from Premium Times and Vanguard Newspapers published within the last two years were examined. Their headlines and content were examined to determine whether the reports contained information that will likely encourage or discourage foreign investors from doing business in and with Nigeria from the first quarter of 2016 to the first quarter of 2017.

\section{Results}

After an examination of two hundred media reports on FDI in the Premium Times and Vanguard Newspapers both online, the following are the relevant and related reports gathered:

Premium Times

1. 58 Nigerian Companies among Fastest Growing In Africa- London Stock Exchange (March 31, 2017)

2. Cadbury Nigeria Plc Announces N562 Million Loss for 2016 (March 22, 2017)

3. Economic Recovery: CBN, Finance Ministry, Others Meet to Harmonise Monetary, Fiscal Policies (March 19, 2017)

4. Finally, Nigeria Inflation Rate Drops the First Time in 15 Months (March 14, 2017)

5. Trade Between Nigeria, South Korea Drops 60 Percent (February 21, 2017)

6. Nigeria's Inflation Rate Increases, Hits 18.72 Percent (February 15, 2017)

7. Why Nigeria's Inflation Will Remain In Double Digits - Afrinvest (January 26, 2017)

8. Global Body Commends Nigeria for Improved Transparency in Extractive Industry (January 18, 2017)

9. Nigeria Inflation Hits $18.55 \%$ (January 14, 2017)

10. Buhari's 2017 Budget Can't End Recession - Economist (December 27, 2016)

11. Nigeria Inflation Hits $18.48 \%$ (December 15, 2016)

12. Nigeria Lost Over N1.5 Trillion to Attacks by Niger Delta Militants, Oil Vandals in 2016 (December 14, 2016)

13. Nigerian equity market loses 0.06 per cent (November 28, 2016)

14. Nigeria's Economic Recession Deepens as GDP Contracts 2.24 Percent in Third Quarter (November 21, 2016)

15. Why Nigeria's Oil, Gas Free Zones Are Prime Destinations for Foreign Investors - Umana (November 18, 2016)

16. Investors Lose N18 Billion on Nigerian Stock Exchange (November 17, 2016) 
17. Nigeria May Not Get Out Of Recession in 2017 - Manufacturers (November 16, 2016)

18. Nigeria Stock Exchange Market Capitalisation Loses N180 Billion (November 8,2016 )

19. Nigerian Equity Market Records 0.12 Per Cent Growth (November 1, 2016)

20. CBN Is Killing Us; We'll Sack 1,500 Staff, Leave Nigeria - Manufacturing Firm (November 1, 2016)

21. Nigeria Gains On Global 'Ease of Doing Business' Ranking (October 27, 2016)

22. Nigeria's Inflation Rises to 17.9 Per Cent in September (October 17, 2016)

23. Recession: National Assembly to Pass 11 Bills for Quick Economic Recovery (October 11, 2016)

24. Nigeria Targets $\$ 4$ Billion Chinese Investment for Oil Industry (October 5, 2016)

25. Naira in Fastest, Biggest Fall yet (September 29, 2016)

26. Guinness Nigeria Records N2 Billion Loss, Blames 'Economic Environment' (September 20, 2016)

27. Mining: Nigeria woos foreign investors with three years tax holiday (September 7,2016 )

28. Buhari Assures Foreign Investors of Security of Nigerian Investments (August 28, 2016)

29. Attacks by Avengers, Others Cut Nigeria's Revenue for July by Almost Half (August 26, 2016)

30. Nigeria's Economy to Contract By $4.1 \%$ in 2016 - IMF (July 19, 2016)

31. Nigeria ranks 4 th with $35 \%$ on investment return in the world - BOI MD (July 16, 2016)

32. Niger Delta Avengers Announces Fresh Attacks on Chevron, NNPC Facilities (July 3, 2016)

33. Why we reduced MTN fine - Nigerian Government (June 19, 2016)

34. U.S. to invest $\$ 600$ million in Nigeria in 2016 (April 1, 2016)
35. How curious $\$ 3.3$ million tax holiday to Shell, Total, Eni, is killing Nigerians (February 23, 2016)

36. Nigerian Capital Market in 2015: Dashed expectations, aspirations in wealth creation (January 2, 2016)

Vanguard

1. NSE: Foreign investments inflow down to N16.10bn in February (March 27, 2017)

2. Recession: Foreign investment inflow down by $\$ 4.5$ bn in 2016 (February 2, 2017)

3. Host communities, foreign investors partner on gas project (December 13, 2016)

4. Foreign investors set to boost healthcare in Nigeria (December 13, 2016)

5. Kidnapping scaring foreign investors from Nigeria -NGE (December 5, 2016)

6. Oil sector attracts $\$ 393 \mathrm{~m}$ foreign investment in 9 month (November 14, 2016)

7. 42 foreign investors arrive Nigeria by Feb. 2017 - Audu Ogbeh (October 24, 2016)

8. Reversal of foreign investment crashes Guinness shares further (October 11, 2016)

9. Repeal of NLNG Act will hamper foreign investments - Lai Mohammed (September 5, 2016)

10. Nigeria's economy in recession with 'record' low foreign investment (August 31, 2017)

11. We will protect foreign investments in Nigeria - Buhari (August 28, 2016)

12. Naira appreciates to N315.93/dollar as foreign investors take advantage ( $\mathrm{Au}-$ gust 25, 2016)

13. CBN's new policy pushes up investments in fixed income (August 11, 2016)

14. FEC relaxes MTN fine to encourage foreign investments, says Shittu (June 19, 2016) 
15. Foreign investors float $\$ 2 \mathrm{bn}$ Infrastructure Fund in Nigeria (June 15, 2016)

16. Foreign Investors still foot-dragging on Nigeria despite electoral success (May $25,2016)$

17. Investors fret as N100bn foreign investment withdrawal deadline (April 29, 2016)

18. Invest in infrastructure, Fashola begs foreign investors (April 26, 2016)

19. Foreign investments in oil hit $\$ 5 \mathrm{bn}$ (April 5, 2016)

20. Foreign investors withdrew N31.84bn from stock market in Feb -NSE (March 25, 2016)

21. Foreign portfolio investments in stock market declines (March 9, 2016)

22. Blowing up of gas installations, kidnapping, killings in Nigeria scare foreign investors - Buhari (February 29, 2016)

23. Foreign investment inflow in oil dips N36bn (February 6, 2017)

The results show that Premium Times had 47 FDI related reports while Vanguard Newspapers had 26 FDI related reports bringing the total number of FDI related reports to 59 within fifteen months under review (January 2016 to March 2017). Of the 59 media reports that could encourage/discourage potential foreign investors, 23 reports appear to be positive for potential foreign investors (in black) while 36 reports have content that will likely not encourage investors (in red). A breakdown is as follows:

\begin{tabular}{|c|c|c|c|c|c|c|}
\hline & \multicolumn{4}{|c|}{2016} & \multirow{2}{*}{$\begin{array}{c}2017 \\
1^{\text {st }} \\
\text { Quar } \\
\text { ter }\end{array}$} & \multirow[b]{2}{*}{$\begin{array}{l}\text { To } \\
\text { tal }\end{array}$} \\
\hline & $\begin{array}{c}1^{\text {st }} \\
\text { Quar } \\
\text { ter }\end{array}$ & $\begin{array}{c}2^{\text {nd }} \\
\text { Quar } \\
\text { ter }\end{array}$ & $\begin{array}{c}3^{r d} \\
\text { Quar } \\
\text { ter }\end{array}$ & $\begin{array}{c}4^{\text {th }} \\
\text { Quar } \\
\text { ter }\end{array}$ & & \\
\hline $\begin{array}{l}\text { Posi } \\
\text { tive }\end{array}$ & 1 & 5 & 6 & 8 & 3 & 23 \\
\hline $\begin{array}{l}\text { Neg } \\
\text { ativ } \\
e\end{array}$ & 5 & 4 & 7 & 12 & 8 & 36 \\
\hline $\begin{array}{l}\text { To- } \\
\text { tal }\end{array}$ & 6 & 9 & 13 & 20 & 11 & 59 \\
\hline
\end{tabular}

ISSN 1330-0067
Foreign direct investment estimated (in UDS millions) to have been imported into Nigeria within January 2016 to March 2017 is as follows:

\begin{tabular}{|c|c|c|c|c|}
\hline \multicolumn{4}{|c|}{2016} & 2017 \\
\hline $\begin{array}{c}1^{\text {st }} \\
\text { Quarter }\end{array}$ & $\begin{array}{c}2^{\text {nd }} \\
\text { Quarter }\end{array}$ & $\begin{array}{c}3^{\text {rd }} \\
\text { Quarter }\end{array}$ & $\begin{array}{c}4^{\text {th }} \\
\text { Quarter }\end{array}$ & $\begin{array}{c}1^{\text {st }} \\
\text { Quarter }\end{array}$ \\
\hline 887.32 & 905.98 & 1386.21 & 1269.22 & 908.27 \\
\hline
\end{tabular}

(Trading Economics, 2017, Invest Advocate, 2017)

\section{Limitations}

One of the limitations of this study is that it considered only two online newspapers, and this cannot sufficiently provide an overview of all reports that may have been published during the period under study. Investors will usually go through a variety of media reports, and there are over thirty newspapers in Nigeria. More newspapers need to be covered in order to reach a more reasonable conclusion. Another important and meaningful approach to it would have been to interview investors to determine whether media reports do influence their choices in investing in an entity or not.

\section{Discussion}

This study was carried out to examine if there is a link between the media reports on foreign direct investments and the inflow of investment to Nigeria. Although the results do not exactly show an exact correspondence between the number of (positive) reports and inflow of FDI, there seems to be a steady increase in the number of positive reports and FDI inflow in the first three quarters of 2016. While it appears that the positive reports show a link the negative reports do not show a pattern at first, but a closer look shows that a decrease in negative reports in a particular quarter is reflected in an increase in FDI in the succeeding quarter. For instance, an increase in the negative report from four to seven in the third quarter could be in a sense linked to the decrease in FDI in the fourth quarter.

Coden: IORME7 
Furthermore, even though it cannot be denied that there are other much stronger and directly linked factors that dictate the inflow of FDI, the influence of the media through daily reports on the political and socioeconomic state of a nation certainly has its influences. And although the findings of this study does not definitively show that there is a link between media reports and foreign direct investments inflow. However, it does not also show that there is no link.

An expansion of this study to include more daily tabloids and trends in the preceding years will increase the possibility of arriving at a definite conclusion. All in all, the media is also a major player in the growth and socioeconomic wellbeing of a nation like Nigeria, and this is so because many still rely on information from the media to determine the state or position of any nation or its government.

\section{Conclusion}

Although this study did not establish a strong link between the portrayal of the economic recession of Nigeria and the inflow of foreign direct investments, it still does not diminish the power of the media to socially construct the reality of various situations and issues. Further studies, bearing in mind the limitations of this study, will firmly determine whether a relationship exists or not.

Notes

/1/ Oguh, C. (2016, December 7). Why Nigeria no longer attracts foreign direct investment - See more at: http://www.financialnigeria.com/why-nigeria-nolonger-attracts-foreign-direct-investment-blog194.html\#sthash. 9f2hBx0t.dpuf. Retrieved from Financial Nigeria: http://www. financialnigeria.com/ why- nigeria -no -longer -attracts- foreign-direct-investment-blog-194.html

/2/ Noko, E. J. (2016, September 10). Economic recession in Nigeria: Causes and Solution. Retrieved from Educacinfo: http:// educacinfo.com/ economic-recession-nigeria/

/3/ Fapohunda, T. M. (2012). The global economic recession: Impact and strategies for human resources management in Nigeria. International Journal of Economics and Management Sciences, $I(6), 7-12$.
/4/ Carvalho, L. (2017, May 16). Nigeria inflation rate: 1996-2017. Retrieved from Trading Economics: https://tradingeconomics.com/ nigeria/ inflationcpi

/5/ Underwood, M. (2008, October 10). The mass media as fourth estate. Retrieved from Namesco: https://frrl.files.wordpress.com/ 2008/ 11/ thefourthestate.pdf

/6/ MDIF. (2014). Media development's role in social, economic and political progress. Retrieved from Media Development Investment Fund: https://www.mdif.org/ wp-content/ uploads/ 2014/ 08/ Media-Developments- Role-in-SocialEconomic- and- Political- Progress- LiteratureReview.pdf

/7/ Population Reference Bureau. (2016). 2106 world population data sheet with a special focus on human needs and sustainable resources. Retrieved from PRB: http://www.prb.org/ pdf16/ prbwpds2016- web- 2016.pdf

/8/ OECD. (2012, September). Nigeria. Retrieved from OECD: http://www.oecd.org/swac/ publications/ Nigeria_e-version_en_light.pdf

19/ Africa Development Bank Group. (2016). Nigeria economic outlook. Retrieved from AFDB: https://www.afdb.org/en/countries/westafrica/nigeria/nigeria-economic-outlook/

/10/ World Bank. (2017). Nigeria: Overvview. Retrieved from World Bank: http://www.worldbank.org/ en/ country/ nigeria/ overview

/11/ Claessens, S., \& Kose, A. M. (2009, March). What is a recession. Finance and development, pp. 52-53. Retrieved from https://www.imf.org/ external/ pubs/ft/ fandd/ 2009/ 03/ pdf/ basics.pdf

112/ Central Bank of Nigeria. (2012). Understanding Monetary Policy Series: Economic recession. Abuja: Central Bank of Nigeria.

/13/ Amadeo, K. (2017, May 1). 11 causes of economic recession. Retrieved from The Balance: https://www.thebalance.com/causes-ofeconomic-recession-3306010

14/ BBC. (2016, August 31). Nigerian economy slips into recession. Retrieved from BBC News Services: http://www.bbc.com/news/business37228741

/15/ IMF. (1977). World Economic Outlook. Washington: International Monetary Fund.

/16/ Olokoyo, F. O. (2012). Foreign direct investment and economic growth: A case of Nigeria. BVIMSR's Journal of Management Research, IV(1), 1-30.

/17/ Duce, M., \& España, B. (2003, July 31). Definitions of Foreign Direct Investment (FDI): a 
Beryl Annette Ehondor, Aifuwa Edosomwan: SOCIAL CONSTRUCTIONISM AND THE EFFECTS OF MEDIA'S PORTRAYAL OF NIGERIA'S ECONOMIC RECESSION ON FOREIGN DIRECT INVESTMENT

Informatol. 54, 2021., 3-4

methodological note. Retrieved from BIS: https://www.bis.org/publ/cgfs22bde3.pdf

/18/ OECD. (2008). OECD benchmark: Definition of foreign direct investment. Retrieved from OECD: https://www.oecd.org/daf/inv/investmentstati sticsandanalysis/40193734.pdf

/19/ Pettinger, T. (2016, February 16). Foreign direct investment. Retrieved from Economics Help: http://www.economicshelp.org/blog/4987/econo mics/foreign-direct-investment/

/20/ Andrews, T. (2012). What is social constructionism? Grounded theory review, XI(1).

/21/ Berger, P. L., \& Luckmann, T. (1966). The social contruction of reality. New York: The Penguin Press.

/22/ Burr, V. (2015). Social constructionism (3rd ed.). London \& New York: Routledge. 